\title{
A Calcium-Induced Calcium Influx Factor, Nitric 0xide, Modulates the Refilling of Calcium Stores in Astrocytes
}

\author{
Nianzhen Li, ${ }^{1}$ Jai-Yoon Sul, ${ }^{2}$ and Philip G. Haydon ${ }^{2}$ \\ ${ }^{1}$ Department of Zoology and Genetics, Iowa State University, Ames, Iowa 50011, and 2Department of Neuroscience, University of Pennsylvania School of \\ Medicine, Philadelphia, Pennsylvania 19104
}

The roles of nitric oxide are primarily undefined in astrocytes, cells that are active partners in synaptic transmission. Because nitric oxide synthases are present in astrocytes, we imaged the formation of nitric oxide in cultured murine cortical astrocytes using DAF-FM (4-amino-5-methylamino-2', $7^{\prime}$-difluorofluorescein diacetate). We demonstrated that physiological concentrations of ATP induced a $\mathrm{Ca}^{2+}$-dependent production of nitric oxide. We then investigated the roles of nitric oxide in astrocytic $\mathrm{Ca}^{2+}$ signaling by exogenous application of a nitric oxide donor and found that nitric oxide induced an influx of external $\mathrm{Ca}^{2+}$. Because these observations raise the possibility that nitric oxide-dependent $\mathrm{Ca}^{2+}$ influx could lead to the refilling of internal stores with $\mathrm{Ca}^{2+}$, we directly monitored the $\mathrm{Ca}^{2+}$ levels of the cytosol and of internal stores while manipulating nitric oxide. Cultures were coloaded with mag-fluo- 4 and X-rhod-1 to differentially load the internal stores and cytosol, respectively. ATP induced a cytosolic increase in $\mathrm{Ca}^{2+}$ that results from the IP ${ }_{3}^{-}$ dependent release of $\mathrm{Ca}^{2+}$ from internal stores, detected as a simultaneous reduction in mag-fluo-4 and an increase in X-rhod-1 fluorescence. To monitor store refilling, we measured the recovery of mag-fluo-4 fluorescence after removal of ATP. When nitric oxide signaling was blocked by the nitric oxide scavenger 2-phenyl-4,4,5,5-ketramethyl-imidazoline-1-oxyl-3-oxide or by the nitric oxide synthase inhibitor $N^{\mathrm{G}}$-monomethyl-L-arginine, fluorescence recovery was significantly reduced. These data suggest that transmitters that induce $\mathrm{Ca}^{2+}$ signaling in astrocytes lead to the $\mathrm{Ca}^{2+}$-dependent synthesis of nitric oxide. This in turn stimulates a $\mathrm{Ca}^{2+}$ influx pathway that is, in part, responsible for the refilling of internal $\mathrm{Ca}^{2+}$ stores.

Key words: nitric oxide; astrocyte; calcium influx; internal calcium stores; DAF-FM; mag-fluo-4; ATP; tripartite synapse

\section{Introduction}

The endogenous gas nitric oxide (NO) was first discovered as a physiological messenger in vascular smooth muscle relaxation (Furchgott and Zawadzki, 1980; Ignarro et al., 1987; Palmer et al., 1987). In the CNS, nitric oxide acts as a membrane-permeant diffusible neurotransmitter that can signal between distant synapses and cells. Nitric oxide has been implicated in neuronal development, synaptic transmission, synaptic plasticity, and in both neuroprotection and neurotoxicity (Lipton et al., 1994; Schuman and Madison, 1994; Jaffrey and Snyder, 1995; Holscher, 1997).

Although there have been many studies on nitric oxide in the nervous system, these studies have focused predominantly on the neuronal synthesis of nitric oxide (Holscher, 1997; Crepel, 1998; Hawkins et al., 1998). Whereas neurons do express nitric oxide synthases, astrocytes, a subtype of glial cell intimately associated with the synapse, express all three forms of nitric oxide synthases

\footnotetext{
Received July 29, 2003; revised Sept. 23, 2003; accepted Sept. 24, 2003.

This work was supported by National Institutes of Health Grants NS43142 and NS37585 (P.G.H.). We thank Yolande Haydon for her editorial assistance on this manuscript.

Correspondence should be addressed to Dr. Philip G. Haydon, Department of Neuroscience, University of Pennsylvania School of Medicine, 36th and Hamilton Walk, 215 Stemmler Hall, Philadelphia, PA 19104-6074. E-mail: pghaydon@mail.med.upenn.edu.

N. Li's present address: Department of Bioengineering, University of Washington, Seattle, WA 98195-2141. Copyright $\odot 2003$ Society for Neuroscience $\quad$ 0270-6474/03/2310302-09\$15.00/0
}

(Murphy, 2000). Whether synaptic activity regulates nitric oxide synthesis in astrocytes is, however, undefined.

Astrocytes are active partners in a "tripartite synapse" comprising the presynaptic and postsynaptic terminals along with the synaptically associated astrocyte (Araque et al., 1999; Volterra et al., 2002). In this arrangement, astrocytes respond to neurochemical stimuli by releasing $\mathrm{Ca}^{2+}$ from internal stores (CornellBell et al., 1990; Charles et al., 1993; Salter and Hicks, 1995; Venance et al., 1997). The elevation of internal astrocytic $\mathrm{Ca}^{2+}$ has many consequences, including the induction of release of the chemical transmitter glutamate (Parpura et al., 1994; Innocenti et al., 2000), which can signal to adjacent neurons (Charles, 1994; Nedergaard, 1994; Parpura et al., 1994; Hassinger et al., 1995; Pasti et al., 1997; Araque et al., 1998a; Bezzi et al., 1998) and modulate neuronal activity (Araque et al., 1998a; Newman and Zahs, 1998; Parpura and Haydon, 2000) and synaptic transmission (Araque et al., 1998b; Kang et al., 1998). Because the activity of neuronal and endothelial nitric oxide synthases are $\mathrm{Ca}^{2+} \mathrm{de}-$ pendent (Griffith and Stuehr, 1995), neurotransmitter-induced $\mathrm{Ca}^{2+}$ elevations in astrocytes have the potential to lead to the formation of nitric oxide. Because of the intimate interactions between blood vessel endothelia cells, astrocytes, and neurons, astrocyte-derived nitric oxide may provide a means for astrocytes to modulate synaptic activity and to control blood flow in response to synaptic activity.

To explore this possibility, we first tested whether nitric oxide 
is generated during astrocytic $\mathrm{Ca}^{2+}$ signaling by imaging nitric oxide in purified murine cortical astrocyte cultures with a fluorescent indicator, DAF-FM (4-amino-5-methylamino-2', $7^{\prime}$ difluorofluorescein diacetate) (Kojima et al., 1999). We found that physiological concentrations of a natural neuromessenger, ATP, induced $\mathrm{Ca}^{2+}$-dependent nitric oxide production. Addition of a nitric oxide donor, $S$-nitrosol- $N$-acetylpenicillamine (SNAP), induced an influx of external $\mathrm{Ca}^{2+}$. Moreover, by simultaneously imaging $\mathrm{Ca}^{2+}$ in cytosol and internal stores, we demonstrated that, by promoting $\mathrm{Ca}^{2+}$ influx, nitric oxide facilitates the refilling of internal stores that become partially depleted as a result of $\mathrm{Ca}^{2+}$ release during neurotransmitter-induced $\mathrm{Ca}^{2+}$ signaling.

\section{Materials and Methods}

Purified cortical astrocyte cultures. Purified cortical astrocyte cultures were prepared as described previously (Parpura et al., 1995). Briefly, postnatal 0- to 2-d-old mice were anesthetized with halothane (Halocarbon Laboratories, River Edge, NJ). After the brain was removed and placed into $\mathrm{Ca}^{2+} / \mathrm{Mg}^{2+}$-free Earle's balanced salt solution (EBSS), $\mathrm{pH}$ 7.35 (Invitrogen, Carlsbad, CA), cortices were dissected and incubated for $1 \mathrm{hr}$ at $37^{\circ} \mathrm{C}$ in EBSS containing papain (20 U/ml), HEPES (10 mM), L-cysteine $(0.2 \mathrm{mg} / \mathrm{ml})$, glucose $(20 \mathrm{~mm})$, penicillin $(100 \mathrm{U} / \mathrm{ml})$, and streptomycin $(100 \mu \mathrm{g} / \mathrm{ml})$. Tissue was washed once with fresh EBSS and then placed in EBSS containing HEPES ( $10 \mathrm{~mm})$ and trypsin inhibitor (10 $\mathrm{mg} / \mathrm{ml}$ ) for $5 \mathrm{~min}$ to stop further digestion. After rinsing, cortices were mechanically dissociated in culture medium by triturating through sterile serological glass pipettes. Culture medium consisted of phenol redfree modified minimum essential medium [Earle's salts (Invitrogen), containing $40 \mathrm{~mm}$ glucose, $2 \mathrm{~mm}$ L-glutamine, $1 \mathrm{~mm}$ pyruvate, $100 \mathrm{U} / \mathrm{ml}$ penicillin, and $100 \mu \mathrm{g} / \mathrm{ml}$ streptomycin] supplemented with $10 \%$ heatinactivated fetal bovine serum (Hyclone, Logan, UT). Cells were plated into $25 \mathrm{~cm}^{2}$ Falcon culture flasks (BD Biosciences, Bedford, MA) and grown to confluence at $37^{\circ} \mathrm{C}$ in a humidified $5 \% \mathrm{CO}_{2}-95 \% \mathrm{O}_{2}$ atmosphere. Cells were fed every 3-4 d by replacing $50 \%$ of the medium with fresh medium. After 7-14 d, the flasks were shaken twice on a horizontal orbital shaker at $260 \mathrm{rpm}$, first for $1.5 \mathrm{hr}$ and then, after replacement with ice-cold medium, for $18 \mathrm{hr}$. The remaining adherent cells were enzymatically detached with trypsin $(0.1 \%)$, pelleted $(800 \times g, 10 \mathrm{~min})$, resuspended in culture medium, and plated onto poly-L-lysine $(1 \mathrm{mg} / \mathrm{ml}$; molecular weight, 40,000-100,000)-coated glass coverslips. The cells were used in experiments after $1-4 \mathrm{~d}$, by which time they had grown to confluence.

Nitric oxide measurement. Relative changes in cytosolic nitric oxide concentration in astrocytes were monitored using the fluorescent nitric oxide probe DAF-FM. Cells were loaded with $10 \mu \mathrm{M}$ DAF-FM diacetate (Molecular Probes, Eugene, OR) for $45 \mathrm{~min}$ at room temperature (20$23^{\circ} \mathrm{C}$ ) in normal external saline containing the following (in $\mathrm{mM}$ ): 140 $\mathrm{NaCl}, 5 \mathrm{KCl}, 2 \mathrm{CaCl}_{2}, 2 \mathrm{MgCl}_{2}, 10 \mathrm{HEPES}, 10$ glucose, and 6 sucrose, $\mathrm{pH}$ 7.35 , and then deacetylated for $45 \mathrm{~min}$. Although a previous nitric oxide indicator, DAF-2 (4, 5-diaminofluorescein), has been reported to undergo photosensitization (Broillet et al., 2001), we did not find any change in intensity of DAF-FM fluorescence under illumination in the conditions described in these experiments.

$\mathrm{Ca}^{2+}$ measurement. $\mathrm{Ca}^{2+}$ levels in astrocytes were imaged using fluorescence microscopy. Unless otherwise specified, cultures were incubated at room temperature for $45 \mathrm{~min}$ in the presence of fluo-3 AM (10 $\mu \mathrm{g} / \mathrm{ml}$; Molecular Probes) and then de-esterified for $45 \mathrm{~min}$.

Simultaneous measurement of cytosolic and internal store $\mathrm{Ca}^{2+}$. In some experiments in which we simultaneously monitored cytosolic and internal store $\mathrm{Ca}^{2+}$ levels, purified cortical astrocyte cultures were first loaded with mag-fluo-4 AM (10 $\mu \mathrm{g} / \mathrm{ml}$; Molecular Probes) at $37^{\circ} \mathrm{C}$ for $45 \mathrm{~min}$, washed, loaded with X-rhod-1 AM $(2.5 \mu \mathrm{g} / \mathrm{ml}$; Molecular Probes $)$ at room temperature for $45 \mathrm{~min}$, and then allowed to de-esterify for $45 \mathrm{~min}$ before imaging.

Image acquisition and processing. In single-dye imaging experiments, coverslips containing dye-loaded cells were visualized using a cooled digital camera (ORCA; Hamamatsu, Hamamatsu City, Japan) attached to a Nikon (Tokyo, Japan) inverted microscope. For experiments using fluo-3, fluo-4, or DAF-FM alone, light from a xenon arc lamp (100 W) was filtered at $480 \mathrm{~nm}$ (480DF10; Omega Optical, Brattleboro, VT) and delivered to the sample through a $20 \times 0.7$ numerical aperture objective. Fluorescent emission was collected through a dichroic mirror (510DRLP; Omega Optical) and filtered with a 515EFLP filter (Omega Optical). Time-lapse images were acquired using either Automation software (Prairie Technologies, Middleton, WI) or Metamorph software (Universal Imaging, West Chester, PA). Frame acquisition interval was 3 sec.

For two-wavelength imaging experiments, dye-loaded cells were excited with 488 and $568 \mathrm{~nm}$ laser lines, and fluorescence was imaged in two channels with a confocal microscope (Prairie Technologies) using Confocal version 1.47 software (Prairie Technologies). A 488/568 nm dual dichroic mirror, which can reflect both 488 and $568 \mathrm{~nm}$ excitation light, was used as the primary dichroic. A 550DRLP dichroic mirror was used between channels 1 and 2. Emission filters for channels 1 and 2 were $610 / 75$ and 525/50 bandpass, respectively. Frame acquisition interval was 6 sec. Because mag-fluo- 4 exhibited some photobleaching in these confocal experiments, we corrected all traces by extrapolation of a linear regression curve that was fit to the control data before addition of ligands. In parallel control experiments using wide-field epifluorescence in which photobleaching was not detected, we confirmed that the use of linear regression curves in confocal studies did not introduce any systematic errors in our results. For example, in this study, we report an overshoot of mag-fluo-4 intensity after store refilling (see Results). This overshoot is not the result of an error introduced by the use of the photo-bleaching correction method because the overshoot was observed when this correction was not applied to cells that exhibited minimal bleaching.

All imaging experiments were performed at room temperature. We used an imaging chamber with a volume of $\sim 150 \mu$ l. Normal external saline as described above (Nitric oxide measurement) was continuously perfused at a rate of $1-2 \mathrm{ml} / \mathrm{min}$, unless otherwise specified.

For quantitative studies, the temporal dynamics in fluorescence were expressed as background-subtracted $d f / F_{0}(\%)$, where $F_{0}$ represents the fluorescence level of the cells before stimulation, and $d f$ represents the change in fluorescence occurring during stimulation of the cell. We report measurements from all of the cells in the imaging fields regardless of their responses to ligands. Statistical differences were established using the Student's $t$ test at $p<0.05, p<0.01$, and $p<0.001$. Data are expressed as mean \pm SEM.

Photolysis. In some experiments, flash photolysis was used to provide a fast localized NO stimulus. Caged NO (potassium nitrosylpentachlororuthenate, $1 \mathrm{~mm}$; Molecular Probes) was included in the external saline. We used a Noran Odyssey confocal upright microscope together with an integrated wide-field fluorescence illumination pathway and an optical pathway for laser excitation for photolysis (Prairie Technologies). A pulsed nitrogen laser (337 nm, $3 \mathrm{nS}$ ) launched into a UV transmitting optical fiber was used for photolysis excitation. A second $635 \mathrm{~nm}$ laser was coupled into the same optical fiber for positioning. The illumination spot on the sample was $\sim 6 \mu \mathrm{m}$. Step motors were used to move the position of the fiber in the image space. Positioning-shuttering of the laser were all controlled by computer software.

Immunocytochemistry. The purity of astrocytes in the purified cortical astrocyte cultures (>99\%) was confirmed by immunocytochemistry. Cultures were fixed with $4 \%$ paraformaldehyde in PBS, pH 7.3, at room temperature for $30 \mathrm{~min}$, rinsed with $\mathrm{PBS}$, and then permeabilized with Triton X-100 (0.25\% in PBS) for $10 \mathrm{~min}$. The cultures were then incubated in PBS containing 5\% BSA, 5\% normal goat serum, $0.25 \%$ Triton $\mathrm{X}-100$, and $0.02 \% \mathrm{NaN}_{3}$ for 30 min to block nonspecific binding. Cultures were incubated with mouse anti-glial fibrillary acidic protein (GFAP) monoclonal antibody (Sigma, St. Louis, MO) and rabbit antimicrotubule-associated protein 2 (MAP-2) polyclonal antibody (Chemicon, Temecula, CA) for $12 \mathrm{hr}$ at $4^{\circ} \mathrm{C}$. Primary antibodies were removed by washing with PBS containing 5\% normal goat serum, $0.25 \%$ Triton $\mathrm{X}-100$, and $0.02 \% \mathrm{NaN}_{3}$ and then incubated with fluorescent dye-labeled secondary antibodies (Alexa Fluor 488 goat anti-mouse IgG and Alexa Fluor 568 goat anti-rabbit IgG; Molecular Probes) for $2 \mathrm{hr}$. The coverslips were mounted in $n$-propyl gallate in glycerol onto glass microscope slides 
and imaged with a laser scanning confocal microscope (Prairie Technologies). The sensitivity of GFAP and MAP-2 antibodies were confirmed by cocultures of cortical astrocytes and neurons

Chemicals. DAF-FM diacetate, fluo-3 AM, fluo-4 AM, mag-fluo 4AM, X-rhod-1 AM, SNAP, 1,2-bis(2-aminophenoxy)ethane- $N, N, N^{\prime}, N^{\prime}$ tetraacetic acid (BAPTA) AM, and potassium nitrosylpentachlororuthenate (caged nitric oxide I) were purchased from Molecular Probes; 2-aminoethoxy-diphenylborate (2-APB), $\mathrm{N}^{\mathrm{G}}$ monomethyl-L-arginine (L-NMMA), and $N^{\mathrm{G}}$ monomethyl-D-arginine (D-NMMA) were purchased from Calbiochem (La Jolla, CA); all other chemicals were purchased from Sigma, unless otherwise specified.

\section{Results}

\section{ATP induces nitric oxide production} in astrocytes

ATP is a critical natural extracellular messenger involved in $\mathrm{Ca}^{2+}$ signaling in astrocytes. It induces an astrocytic $\mathrm{Ca}^{2+}$ elevation and mediates the propagation of $\mathrm{Ca}^{2+}$ waves between astrocytes (Guthrie et al., 1999). Activities of neuronal nitric oxide synthase and endothelial nitric oxide synthase are known to be $\mathrm{Ca}^{2+}$ dependent (Griffith and Stuehr, 1995; Gross and Wolin, 1995). Therefore, we asked whether ATP can induce nitric oxide production using the nitric oxide-sensitive fluorescence indicator DAF-FM. Application of $10 \mu \mathrm{M}$ ATP induced a small but reliable increase of DAF-FM fluorescence (Fig. 1) in $97.5 \pm 1.3 \%$ of the cells studied ( $n=15$ experiments, 683 cells). Control experiments confirmed that the increase in DAF-FM fluorescence was attributable to nitric oxide production, because both the membrane-permeant nitric oxide scavenger 2-phenyl-4,4,5,5ketramethyl-imidazoline-1-oxyl-3-oxide (PTIO) (100 $\mu \mathrm{M}, 5 \mathrm{~min}$ incubation) (Akaike et al., 1993) (Fig. 1D) and the nitric oxide synthase inhibitor L-NMMA (300 $\mu \mathrm{M}, 30 \mathrm{~min})$, but not its inactive analog D-NMMA (300 $\mu \mathrm{M}, 30 \mathrm{~min})$, blocked the ATPinduced DAF-FM fluorescence increase (Fig. $1 B, E$ ).

\section{$\mathrm{Ca}^{2+}$ is necessary for ATP-induced nitric oxide production}

Because the activity of nitric oxide synthases are $\mathrm{Ca}^{2+}$ dependent and because ATP induces a $\mathrm{Ca}^{2+}$ elevation in astrocytes, it is logical to test whether a $\mathrm{Ca}^{2+}$ elevation is required for the ATPinduced nitric oxide production. To test this hypothesis, we chelated the cytosolic $\mathrm{Ca}^{2+}$ by incubating astrocytes in BAPTA AM $(30 \mu \mathrm{M}$, $45 \mathrm{~min})$. In the presence of BAPTA, ATP no longer induced an increase in DAF-FM fluorescence (four experiments each; $p<$ 0.001) (Fig. 2D). Separate experiments involving imaging with the $\mathrm{Ca}^{2+}$ indicator fluo-3 confirmed that BAPTA blocked the $\mathrm{Ca}^{2+}$ increase caused by ATP (three experiments each; $p<0.001$ ) (Fig. $2 C)$. The addition of thapsigargin $(10 \mu \mathrm{M})$ to cultures, which blocks the $\mathrm{Ca}^{2+}$-ATPase of internal stores and leads to an elevation of cytosolic calcium, caused a $2.97 \pm 0.29 \%(n=101$ cells $)$ increase in DAF-FM fluorescence. These results demonstrate that an increase in internal $\mathrm{Ca}^{2+}$ is necessary for ATP-induced nitric oxide production. In addition, when astrocytes were treated with PPADS $(50 \mu \mathrm{M}, 5$ min), an antagonist for $\mathrm{P}_{2}$ receptors, the ATP-induced nitric oxide production was also inhibited ( $n=150,4$ experiments) (Fig. $2 B$ ). The effectiveness of PPADS in blocking astrocytic $\mathrm{Ca}^{2+}$ elevation
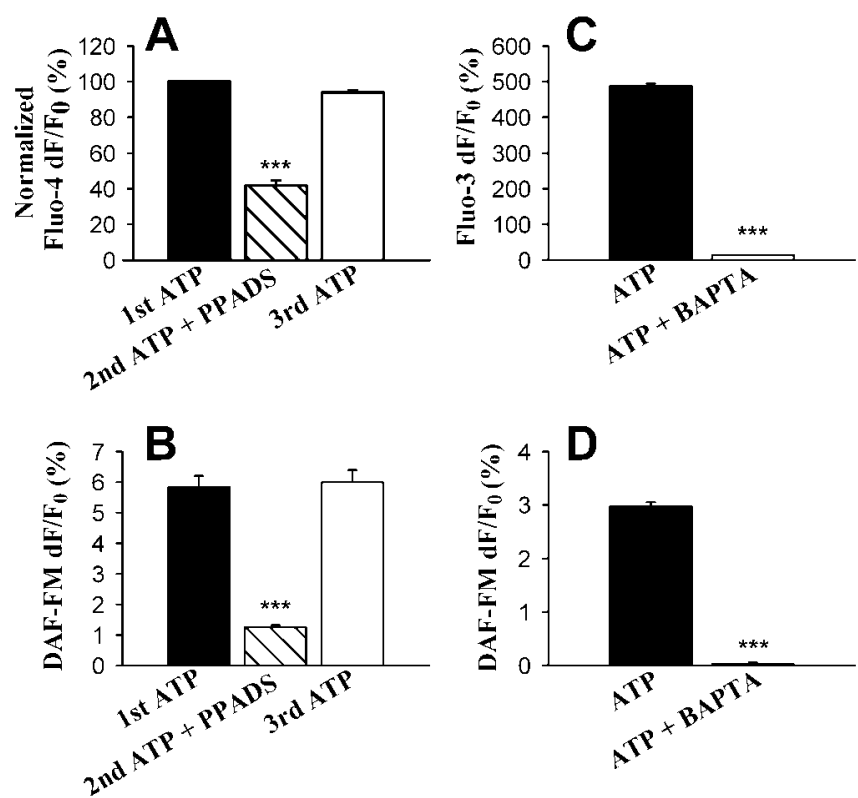

Figure 2. ATP-induced nitric oxide production is $\mathrm{P}_{2}$ receptor mediated and $\mathrm{Ca}^{2+}$ dependent. $A_{\text {, }}$ Treatment with the $P_{2}$ receptor antagonist PPADS (50 $\mu \mathrm{m}, 5 \mathrm{~min}$ ) inhibited the $\mathrm{Ca}^{2+}$ elevation caused by ATP ( $n=195$ cells, 4 experiments). $B$, Treatment with PPADS significantly reduced the amplitude of ATP-induced DAF-FM fluorescence increase ( $n=150$ cells, 4 experiments). C, After cells were incubated with the $\mathrm{Ca}^{2+}$ chelator BAPTA (BAPTA AM at $30 \mu \mathrm{m}, 45 \mathrm{~min}$ ), ATP-induced $\mathrm{Ca}^{2+}$ elevation was blocked ( $n=242$ cells in BAPTA and 316 cells in control conditions, 3 experiments each). $D$, Treatment with BAPTA (BAPTA AM at $30 \mu \mathrm{m}, 45 \mathrm{~min}$ ) significantly reduced the amplitude of ATP-induced DAF-FM fluorescence increase ( $n=240$ cells in BAPTA and 174 cells in control conditions, 4 experiments each). Statistical differences were established using the Student's $t$ test at ${ }^{*} p<$ $0.05,{ }^{* *} p<0.01$, and ${ }^{* * *} p<0.001$. Error bars indicate SEMs. 

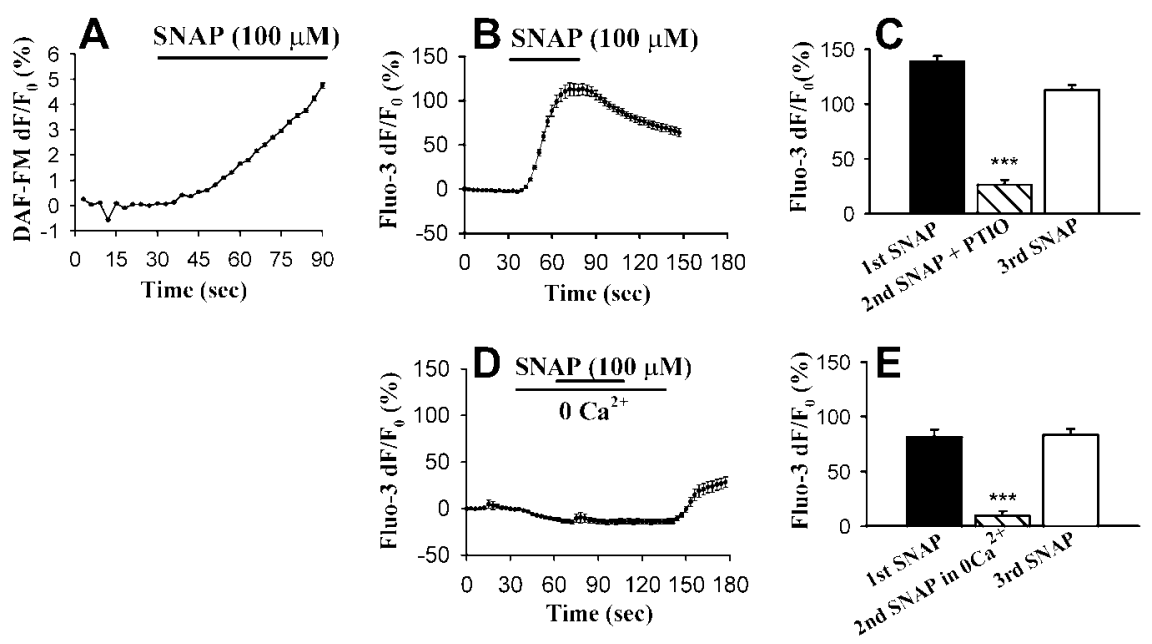

Figure 3. Thenitric oxide donor SNAP induces an influx of external $\mathrm{Ca}^{2+}$ into astrocytes. $A, \operatorname{SNAP}(100 \mu \mathrm{m})$, a nitric oxide donor, caused an increase in cellular DAF-FM fluorescence, confirming that SNAP spontaneously releases nitric oxide in saline. B, Typical astrocytic $\mathrm{Ca}^{2+}$ increase in response to SNAP. Astrocytes were loaded with fluorescent $\mathrm{Ca}^{2+}$ indicator fluo-3. Cells were stimulated by perfusion with SNAP $(100 \mu \mathrm{m}, 45 \mathrm{sec})$. The trace is the average of all of the cells in the imaging field ( $n=31$ cells). Error bars are SEMs. C, Nitric oxide is responsible for the SNAP-induced $\mathrm{Ca}^{2+}$ increase as the nitric oxide scavenger PTIO inhibited the fluo-3 fluorescence increase caused by SNAP. Three application protocols were used. The first and third SNAP applications were used as internal controls for each cell ( $n=114$ cells, 3 experiments). D, After washing with normal saline for $10 \mathrm{~min}$, the same cells as shown in B were treated with zero-Ca ${ }^{2+}$ saline for $30 \mathrm{sec}$ and stimulated with SNAP again. This time, little $\mathrm{Ca}^{2+}$ change was induced by SNAP.E, The summary histogram shows that the second SNAP application in zero- $\mathrm{Ca}^{2+}$ saline induced a smaller astrocytic $\mathrm{Ca}^{2+}$ increase than the first (control) and third (recovery) applications in normal saline ( $n=84$ cells, 4 experiments). Statistical differences were established using the Student's test at ${ }^{*} p<0.05,{ }^{* *} p<0.01$, and $^{* * *} p<0.001$. Error bars indicate SEMs.

was confirmed by $\mathrm{Ca}^{2+}$ imaging experiments in which PPADS reversibly inhibited ATP-induced cytosolic $\mathrm{Ca}^{2+}$ elevation in astrocytes (Fig. 2A). This is consistent with a $\mathrm{P}_{2}$ receptor-mediated $\mathrm{Ca}^{2+}$ elevation stimulating nitric oxide production.
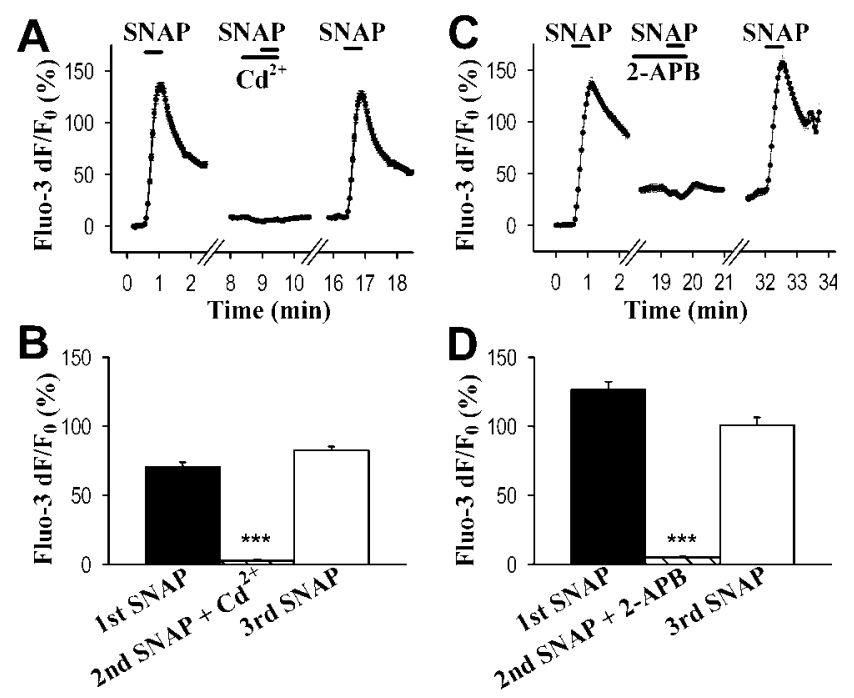

Figure 4. External $\mathrm{Cd}^{2+}$ and 2-APB block the SNAP-induced $\mathrm{Ca}^{2+}$ elevation in astrocytes, suggesting that nitric oxide induces a $\mathrm{Ca}^{2+}$ influx through store-operated channels. $A$, An example of an experiment trace showing that $\mathrm{Cd}^{2+}$ (a nonspecific $\mathrm{Ca}^{2+}$ channel blocker; 100 $\mu \mathrm{m})$ blocked SNAP-induced $\mathrm{Ca}^{2+}$ influx. The first and third SNAP applications were performed in normal saline, whereas the second SNAP application was performed in the presence of $\mathrm{Cd}^{2+}$. $B$, Summary histogram of the effect of $\mathrm{Cd}^{2+}$ on SNAP-induced $\mathrm{Ca}^{2+}$ influx ( $n=205$ cells, 3 experiments). C, 2-APB (75 $\mu \mathrm{m}, 10 \mathrm{~min})$, an $\mathrm{IP}_{3}$ receptor antagonist and capacitive $\mathrm{Ca}^{2+}$ entry inhibitor, reduced SNAP-induced $\mathrm{Ca}^{2+}$ increase significantly. Similar protocols were used as in A. D, Summary histogram of the effect of 2-APB on SNAP-induced $\mathrm{Ca}^{2+}$ influx ( $n=96$ cells, 3 experiments). Statistical differences were established using the Student's $t$ test at ${ }^{*} p<0.05$, ${ }^{* *} p<0.01$, and ${ }^{* * *} p<0.001$. Error bars indicate SEMs.

\section{Nitric oxide induces a $\mathrm{Ca}^{2+}$ influx into astrocytes}

The observation that nitric oxide can be produced in astrocytes via a $\mathrm{Ca}^{2+}$ dependent mechanism led to the following question: what are the roles of nitric oxide in astrocytes? Nitric oxide has been shown to modulate $\mathrm{Ca}^{2+}$ signaling in other cell types via a cGMP-dependent pathway or via direct nitrosylation of proteins (Willmott et al., 1995, 1996; Guihard et al., 1996; Rooney et al., 1996; Lee, 1997; Volk et al., 1997; Berkels et al., 2000; Loitto et al., 2000; Looms et al., 2001), but its roles in astrocytes are primarily unknown. Because $\mathrm{Ca}^{2+}$ excitability is an essential characteristic of astrocytes, we investigated whether nitric oxide can modulate $\mathrm{Ca}^{2+}$ signaling in astrocytes.

To test the effects of nitric oxide on astrocyte $\mathrm{Ca}^{2+}$ signaling, we applied the nitric oxide donor SNAP, which spontaneously releases nitric oxide (Fig. $3 A$ ) in saline, to astrocytes and asked whether nitric oxide can induce a $\mathrm{Ca}^{2+}$ elevation. Figure $3 B$ shows that perfusion with 100 $\mu \mathrm{M}$ SNAP increased $\mathrm{Ca}^{2+}$ levels in $96.5 \pm$ $1.5 \%$ of the astrocytes ( $n=13$ experiments, 500 cells), an effect that was reversibly blocked by addition of the nitric oxide scavenger PTIO ( 100 $\mu \mathrm{M} ; n=114$ cells, 3 experiments; $p<0.001$ ) (Fig. $3 C$ ), which confirmed that this $\mathrm{Ca}^{2+}$ increase is evoked by the action of nitric oxide, not that of SNAP. Additionally, we performed flash photolysis to photorelease nitric oxide from caged $\mathrm{NO}(1 \mathrm{mM})$. Application of one $3 \mathrm{nS}, 337 \mathrm{~nm}$ UV pulse induced an elevation of astrocytic calcium. Photolysis caused the fluorescence of fluo-3 to increase by $691.4 \pm 260.2 \%(n=6)$. The increase in intracellular $\mathrm{Ca}^{2+}$ was not attributable to UV exposure, because when the same UV pulse was delivered to astrocytes in the absence of the caged compound, astrocytes did not show a $\mathrm{Ca}^{2+}$ elevation (fluo-3 df/F, $1.8 \pm 1.2 \% ; n=4$ ). In another set of control experiments, the NO scavenger PTIO $(100 \mu \mathrm{M})$ prevented flash photolysis of caged NO from inducing a Ca ${ }^{2+}$ elevation (fluo- $3 \mathrm{df} / \mathrm{F}_{0}$, $7.8 \pm 3.2 \% ; n=3$ ), confirming that flash photolysis normally induces a $\mathrm{Ca}^{2+}$ signal as a result of the liberation of NO. It is not clear why PTIO more effectively blocked the ability of photoreleased nitric oxide compared with SNAP to elevate astrocytic $\mathrm{Ca}^{2+}$. Regardless of these quantitative differences, the results of these two experiments support the idea that nitric oxide causes a $\mathrm{Ca}^{2+}$ elevation in astrocytes.

Whereas the nitric oxide donor SNAP can induce a $\mathrm{Ca}^{2+}$ increase in astrocytes, the cGMP pathway agonist 8-Br-cGMP (up to $3 \mathrm{~mm}$ ) did not induce any detectable change in fluo-3 fluorescence ( $n=4$ experiments) (data not shown), suggesting that the cGMP pathway is not involved in the nitric oxideinduced $\mathrm{Ca}^{2+}$ signaling in astrocytes.

To determine whether nitric oxide stimulates $\mathrm{Ca}^{2+}$ influx or release from internal stores, we determined the effect of bathing cells in $\mathrm{Ca}^{2+}$-deficient saline. Interestingly, when $100 \mu \mathrm{M}$ SNAP was applied to the same cells in zero- $\mathrm{Ca}^{2+}$ external saline, it no longer induced an increase in intracellular $\mathrm{Ca}^{2+}$; however, when reapplied in the presence of external $\mathrm{Ca}^{2+}$, SNAP could again 
induce cytosolic $\mathrm{Ca}^{2+}$ elevations (Fig. $3 D, E)$. This suggests that nitric oxide stimulates a $\mathrm{Ca}^{2+}$ influx pathway in astrocytes.

Cadmium $\left(\mathrm{Cd}^{2+}\right)$, a nonselective $\mathrm{Ca}^{2+}$ channel blocker $(100 \mu \mathrm{M})$, and $2-\mathrm{APB}$, an $\mathrm{IP}_{3}$ receptor antagonist and capacitative $\mathrm{Ca}^{2+}$ entry blocker $(75 \mu \mathrm{M})$ (Bootman et al., 2002), also reversibly blocked SNAP-induced $\mathrm{Ca}^{2+}$ elevations (Fig. 4). $\mathrm{Cd}^{2+}$ reduced the average SNAPinduced change in fluo-3 fluorescence to $2.9 \pm 0.5 \%$ compared with $70.6 \pm 3.4 \%$ in the first SNAP application $(n=205$ cells, 3 experiments). The average fluo- $3 d f / F_{0}$ induced by SNAP in 2-APB-treated cells was $2.9 \pm 0.5 \%$ compared with $138.7 \pm 5.2 \%$ in the first SNAP application $(n=96$ cells, 3 experiments). In conclusion, these results show that nitric oxide raises astrocytic $\mathrm{Ca}^{2+}$ by inducing an influx of extracellular $\mathrm{Ca}^{2+}$ and possibly by activating a capacitative $\mathrm{Ca}^{2+}$ entry pathway.

\section{Nitric oxide modulates the refilling of internal $\mathrm{Ca}^{2+}$ stores}

It has been shown that many neurotransmitters (e.g., ATP, glutamate, and norepinephrine) induce an elevation in intracellular $\mathrm{Ca}^{2+}$ in astrocytes by causing $\mathrm{IP}_{3}$ mediated release of $\mathrm{Ca}^{2+}$ from internal $\mathrm{Ca}^{2+}$ stores (Cornell-Bell et al., 1990; Charles et al., 1993; Salter and Hicks, 1995; Venance et al., 1997), but the mechanism by which these internal $\mathrm{Ca}^{2+}$ stores are refilled is primarily undetermined. Capacitative $\mathrm{Ca}^{2+}$ entry, or store depletioninduced store refilling, has been inten-

sively investigated in several other cell types (Putney, 1977; Lewis and Cahalan, 1989; Hoth and Penner, 1993; Clapham, 1995; Zhang and McCloskey, 1995; Birnbaumer et al., 1996; Parekh and Penner, 1997; Putney and McKay, 1999; van Rossum et al., 2000; Clapham et al., 2001) but has not been widely studied in astrocytes. Because an ATP-induced $\mathrm{Ca}^{2+}$ elevation can induce nitric oxide production in astrocytes and because nitric oxide can induce external $\mathrm{Ca}^{2+}$ influx, it is possible that nitric oxide production is responsible for refilling internal $\mathrm{Ca}^{2+}$ stores.

Simultaneous monitoring of cytosolic and internal store $\mathrm{Ca}^{2+}$

To test further for a role for nitric oxide signaling in the regulation of $\mathrm{Ca}^{2+}$ levels of internal stores, we directly imaged relative $\mathrm{Ca}^{2+}$ levels of internal stores using the low-Ca ${ }^{2+}$ affinity fluorescent indicator mag-fluo-4. When cells were incubated with magfluo- $4 \mathrm{AM}$ at $37^{\circ} \mathrm{C}$, loading of this dye into intracellular compartments was facilitated. Because the $K_{\mathrm{d}(\mathrm{Ca}+)}$ of mag-fluo- 4 is 22 $\mu \mathrm{M}$ and the $\mathrm{Ca}^{2+}$ level in stores is $\sim 153 \mu \mathrm{M}$ (Golovina and Blaustein, 2000), whereas cytosolic $\mathrm{Ca}^{2+}$ concentration is $\sim 100$ $\mathrm{nM}$, this indicator preferentially reports store $\mathrm{Ca}^{2+}$ levels. After loading with mag-fluo-4, astrocytes were then loaded with the high-affinity $\mathrm{Ca}^{2+}$ indicator X-rhod-1 AM ( $K_{\mathrm{d}(\mathrm{Ca} 2+)}$ of $\left.700 \mathrm{nM}\right)$ at room temperature. Because AM dyes are less likely to compartmentalize into internal stores when loaded at room temperature
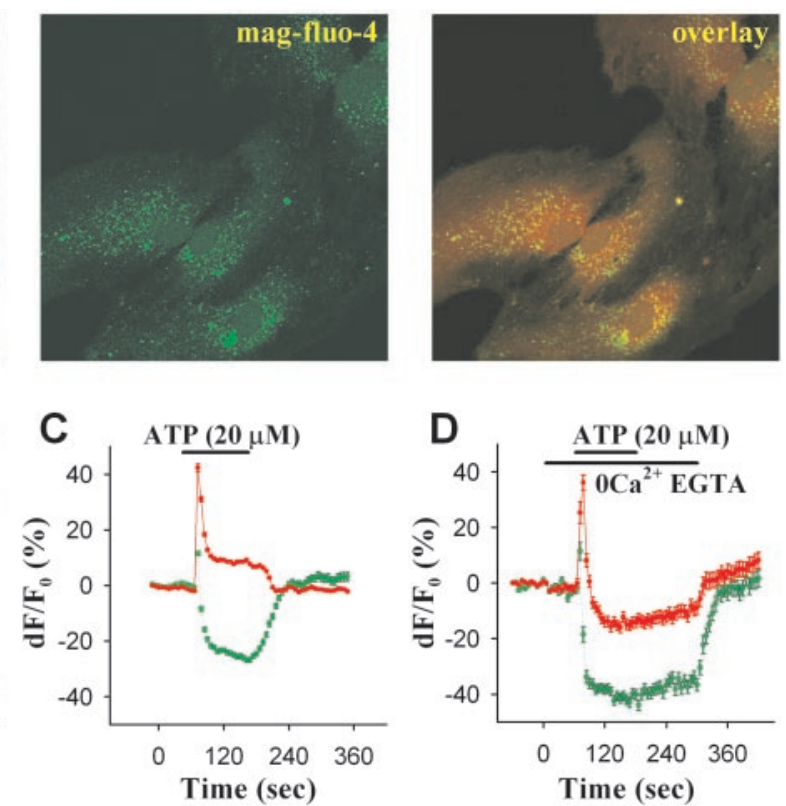

Time (sec)

Figure 5. Simultaneous monitoring of astrocytic $\mathrm{Ca}^{2+}$ levels in cytosol and internal stores, respectively, by coloading with two 作

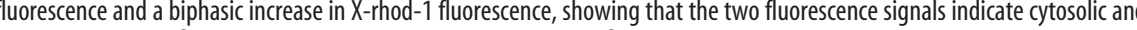
ATP, but, in the presence of zero-Ca ${ }^{2+}$ EGTA, the ATP-induced reduction in mag-fluo-4 fluorescence could not recover after the removal of ATP until $\mathrm{Ca}^{2+}$ was reintroduced into the bath, and the increase in X-rhod-1 fluorescence lacked an elevated plateau phase, both consistent with the effects of an elimination of $\mathrm{Ca}^{2+}$ influx.

and because the $K_{\mathrm{d}(\mathrm{Ca} 2+)}$ of X-rhod-1 is in the operating range of $\mathrm{Ca}^{2+}$ in the cytosol, it preferentially reports cytosolic $\mathrm{Ca}^{2+}$ levels.

Examples of astrocytes coloaded with mag-fluo-4 and X-rhod-1 are shown in Figures $5 A$ and 6 . Note that X-rhod-1 staining is more homogenous, whereas mag-fluo-4 staining shows clear punctate patterns in the periphery of cells and is devoid of fluorescence in nuclear regions, consistent with X-rhod-1 and mag-fluo-4 loading into cytosol and internal stores, respectively. To test whether these indicators do indeed report the $\mathrm{Ca}^{2+}$ levels in the two different compartments, we applied thapsigargin, an irreversible endoplasmic reticulum (ER) $\mathrm{Ca}^{2+}$-ATPase inhibitor. In the presence of thapsigargin, $\mathrm{Ca}^{2+}$ leaks from the ER, causing cytosolic $\mathrm{Ca}^{2+}$ to increase and internal stores to gradually become depleted. As shown in Figure $5 B$, thapsigargin reduced mag-fluo-4 fluorescence and increased X-rhod-1 fluorescence at the same time ( $n=4$ experiments). These results confirm that we were simultaneously monitoring cytosolic and internal store $\mathrm{Ca}^{2+}$ with X-rhod-1 and mag-fluo-4. Although mag-fluo-4 may be loading into other stores and organelles, we will refer to the mag-fluo- 4 fluorescence as an indicator of internal $\mathrm{Ca}^{2+}$ stores. One concern is whether mag-fluo-4 $\left(K_{\mathrm{d}(\mathrm{Ca} 2+)}\right.$ of $\left.20 \mu \mathrm{M}\right)$ is saturated in internal stores. However, a previous study has demonstrated that this indicator is not saturated in this location (Shmigol et al., 2001), a conclusion that our data support given that we see an overshoot of mag-fluo-4 fluo- 

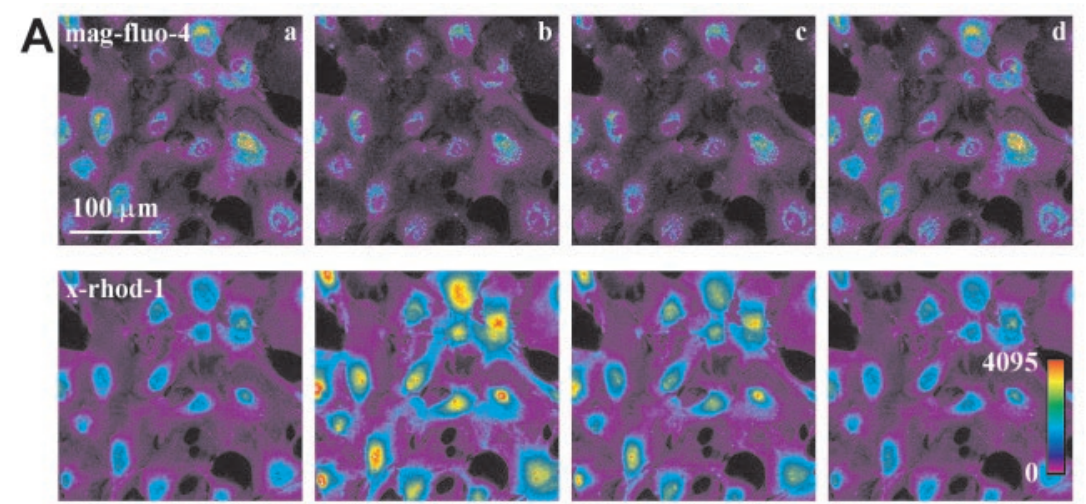

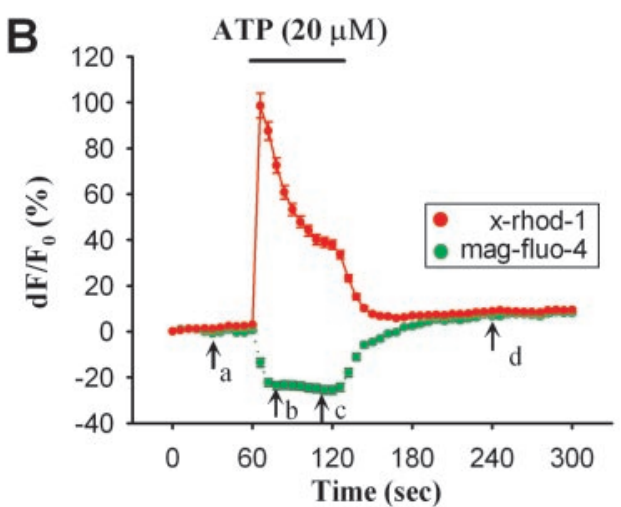

Figure 6. ATP induces release of $\mathrm{Ca}^{2+}$ from internal stores and subsequent store refilling. $A$, An example experiment showing that the ATP $(20 \mu \mathrm{M})$ evoked increase in cytosolic $C \mathrm{a}^{2+}$ results from the release of $\mathrm{Ca}^{2+}$ from internal stores. These images are pseudocolor images of mag-fluo- 4 and X-rhod-1 fluorescence corresponding to times labeled in the graph in $B$ ( $a$, 30 sec before ATP application; $b, 10$ sec after starting ATP; $c, 40$ sec after starting ATP; $d, 2$ min after removal of ATP showing full recovery). Note that mag-fluo-4 fluorescence decreased and X-rhod-1 fluorescence increased in response to ATP, but, 2 min after the removal of ATP, both signals returned to their base levels. $B$, Traces showing the average changes in mag-fluo- 4 and $X$-rhod- 1 fluorescence of the cells in $A$.

rescence intensity after internal stores refill with calcium (Fig. $6 B)$.

ATP is a neurotransmitter that is known to induce $\mathrm{Ca}^{2+}$ release from the ER via the $\mathrm{IP}_{3}$ pathway; therefore, to further confirm the validity of the two-indicator approach in reporting changes in cytosolic and internal stores of $\mathrm{Ca}^{2+}$, we applied ATP to astrocytes. In response to ATP, X-rhod-1 fluorescence exhibited a biphasic increase with a short-latency peak, followed by a plateau, consistent with the known biphasic cytosolic $\mathrm{Ca}^{2+}$ increase of ATP. Concurrent with the increase in cytosolic $\mathrm{Ca}^{2+}$ was a reduction in the fluorescence of mag-fluo-4, consistent with the reduction of internal stores of $\mathrm{Ca}^{2+}$ caused by $\mathrm{Ca}^{2+}$ release from stores (Fig. $5 C$ ). When ATP was then applied to the same cells in the presence of zero-Ca ${ }^{2+} 1$ mM EGTA, X-rhod-1 fluorescence increased, but this increase lacked an elevated plateau phase, and mag-fluo-4 fluorescence decreased in a larger magnitude than in $\mathrm{Ca}^{2+}$-containing saline (Fig. $5 D$ ). After washout of ATP, mag-fluo-4 fluorescence did not recover until $\mathrm{Ca}^{2+}$ was added back into the saline, consistent with the elimination of $\mathrm{Ca}^{2+}$ influx and the refilling of internal store with zero-Ca ${ }^{2+}$ EGTA. These results are all consistent with X-rhod-1 and magfluo-4 monitoring cytosolic and internal stores of $\mathrm{Ca}^{2+}$, respectively.

Occasionally, a small initial transient increase in mag-fluo-4 fluorescence was observed in response to ATP (Fig. 5C,D). This small increase was abolished after cells were treated briefly with BAPTA (BAPTA AM at $30 \mu \mathrm{M}, 20 \mathrm{~min} ; n=3$ experiments) (data not shown), suggesting that a small amount of mag-fluo-4 was present in the cytosol. Because we are mainly interested in the magnitude of store depletion and refilling after this transient increase, mag-fluo-4 can still be used as an indicator of internal stores of $\mathrm{Ca}^{2+}$ despite this minor contaminating cytosolic signal. Together, these results support the notion that the two indicators, X-rhod-1 and mag-fluo-4, preferentially report changes in cytosolic and internal stores of $\mathrm{Ca}^{2+}$, respectively, and that they can be used for investigating the role of nitric oxide in the regulation of $\mathrm{Ca}^{2+}$ store refilling.

Blockade of nitric oxide signaling reduces the refilling of internal $\mathrm{Ca}^{2+}$ stores

To investigate the role of nitric oxide in store refilling, we directly visualized ATP-induced store depletion and subsequent store refilling and asked whether nitric oxide modulates store refilling.
Figure 6 demonstrates the results from one such experiment using ATP. Both the images and the trace show the ATP $(20 \mu \mathrm{M}, 60$ sec)-induced cytosolic $\mathrm{Ca}^{2+}$ elevation resulting from release of $\mathrm{Ca}^{2+}$ from internal stores. Note that the internal stores were able to be fully refilled $2 \mathrm{~min}$ after removal of ATP (Fig. $6 B, d$ ). Moreover, because the fluorescence intensity of mag-fluo- 4 after refilling exceeded the prestimulus level, it is clear that this calcium indicator is not saturated by the levels of calcium within the internal stores.

The effect of nitric oxide on the refilling of internal stores was then studied by blockade of nitric oxide signaling with the nitric oxide scavenger PTIO. Figure 7 shows that, when cells were pretreated with PTIO $(100 \mu \mathrm{M}, 10 \mathrm{~min})$, internal stores were no longer able to refill fully, because mag-fluo-4 fluorescence did not recover to its prestimulation fluorescence intensity. In the presence of PTIO, mag-fluo-4 fluorescence recovered only to $71.2 \pm$ $5.0 \%$ of its initial prestimulus value $2 \mathrm{~min}$ after removal of ATP as opposed to $104.5 \pm 7.7 \%$ in control conditions ( $n=9$ experiments; $p<0.01$ ) (Fig. 7C). Consistent with this finding, treatment with the nitric oxide synthase inhibitor L-NMMA, but not its inactive analog D-NMMA, also significantly reduced the refilling percentage of internal stores $(n=9,6$, and 7 experiments for control, L-NMMA-treated, and D-NMMA-treated groups, respectively) (Fig. 7C). These findings directly support the hypothesis that nitric oxide modulates the refilling of internal $\mathrm{Ca}^{2+}$ stores.

\section{Discussion}

Using the nitric oxide-sensitive fluorescent indicator DAF-FM, we observed that ATP, an important messenger in astrocytic $\mathrm{Ca}^{2+}$ waves, induced the production of nitric oxide in purified astrocyte cultures. Our data are consistent with the notion that the cytosolic $\mathrm{Ca}^{2+}$ elevation, rather than the depletion of internal store $\mathrm{Ca}^{2+}$, is responsible for nitric oxide production. Because the $\mathrm{P}_{2}$ receptor antagonist PPADS and the $\mathrm{Ca}^{2+}$-chelator BAPTA both inhibited the ATP-induced nitric oxide production, this nitric oxide production must be $\mathrm{P}_{2}$ receptor mediated and $\mathrm{Ca}^{2+}$ dependent. To our knowledge, this is the first report to directly visualize nitric oxide production in astrocytes induced by a natural cellular messenger such as ATP. Although we could not differentiate the specific isoforms of nitric oxide synthase with our pharmacological studies, it is likely that $\mathrm{Ca}^{2+}$-dependent nitric 
A

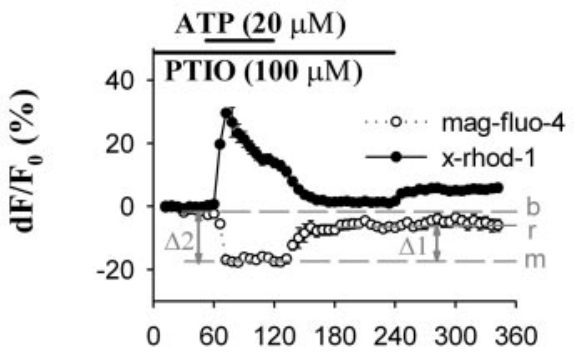

Time (sec)

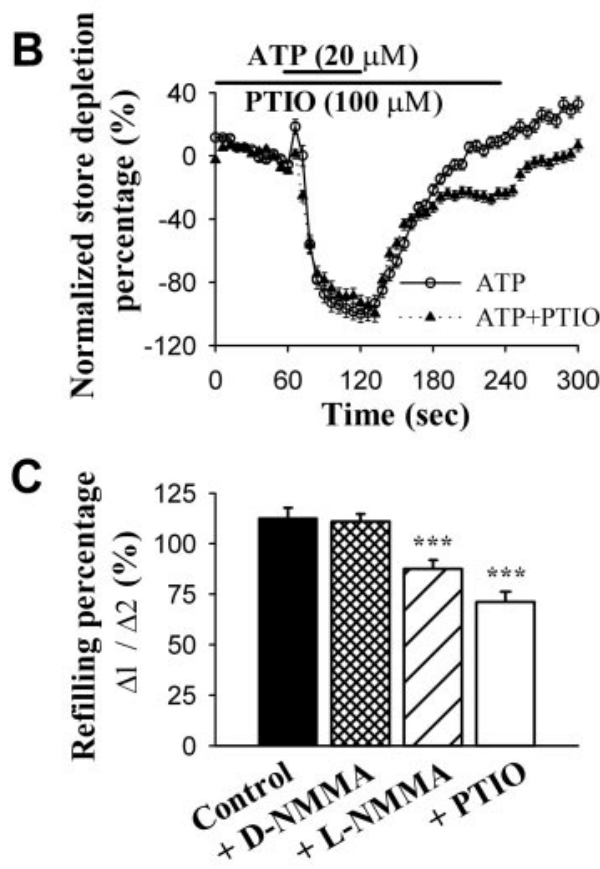

Figure 7. Inhibition of nitric oxide accumulation reduces the refilling of internal $\mathrm{Ca}^{2+}$ stores. A, Example traces of one experiment showing the ATP-induced elevation of cytosolic $\mathrm{Ca}^{2+}$ and depletion of internal store $\mathrm{Ca}^{2+}$ and subsequent store refilling in PTI0-treated cells. Note that, unlike control conditions (Fig. 6), internal $\mathrm{Ca}^{2+}$ store refilled only partially in the presence of PTIO. The horizontal lines in the graph are artificial lines drawn to indicate the baseline level ( $b$; average of 3 frames immediately before ATP application), maximum decrease $(\mathrm{m})$ and recovered level ( $r$; average of three frames before $2 \mathrm{~min}$ post-ATP removal) of magfluo- $4 \mathrm{df} / \mathrm{F}_{0} . \Delta 1$ and $\Delta 2$ represent the differences between $\mathrm{r}$ and $\mathrm{m}$, and $\mathrm{b}$ and $\mathrm{m}$, respectively. $B$, The time course of the changes in internal store $\mathrm{Ca}^{2+}$ level under control conditions and in PTIO-treated cells, demonstrating that internal stores did not fully refill in the presence of PTIO compared with the control conditions (experiments performed in parallel). The data points represent the average of all cells in all experiments for each group. C, Summary histograms showing that store refilling $(\Delta 1 / \Delta 2 * 100$ ) is reduced by the N0 scavenger PTIO ( $n=9$ experiments), as well as by the NOS inhibitor L-NMMA ( $n=6$ experiments) but not by its inactive analog D-NMMA ( $n=7$ experiments). Statistical differences were established using the Student's $t$ test at ${ }^{*} p<0.05,{ }^{* *} p<0.01$, and ${ }^{* * *} p<0.001$. Error bars indicate SEMs.

oxide synthases (endothelial nitric oxide synthases and neuronal nitric oxide synthases) are responsible on the basis of the $\mathrm{Ca}^{2+}$ dependence of this ATP-induced production. Nitric oxide has numerous actions in the CNS and is considered a "double-edged sword" because of its neuromodulatory and neuroprotective roles at low concentrations and its neurotoxic roles at high concentrations, usually attributable to the activation of inducible nitric oxide during pathological conditions. Although DAF-FM does not quantitatively measure nitric oxide levels, it is reasonable to speculate that this astrocytic $\mathrm{Ca}^{2+}$-dependent nitric oxide synthesis would be in the physiological range and is therefore involved in the modulation of normal information processing.
However, it will be important to validate these studies using brain slice preparations studied at physiological temperatures. Because synaptic activity in brain slices is known to elevate the $\mathrm{Ca}^{2+}$ levels of astrocytes (Dani et al., 1992; Porter and McCarthy, 1996), it will be intriguing to determine whether synaptic stimulation cause the synthesis of nitric oxide in this non-neuronal source, as well as in postsynaptic spines (Brenman et al., 1996; Brenman and Bredt, 1997; Burette et al., 2002), and whether astrocytederived nitric oxide regulates neurons and the vasculature.

When the nitric oxide donor SNAP was applied to purified astrocyte cultures, it induced a nitric oxide-dependent $\mathrm{Ca}^{2+}$ increase in astrocytes. This increase in $\mathrm{Ca}^{2+}$ was attributable to an influx of $\mathrm{Ca}^{2+}$ from the extracellular space, because both zero$\mathrm{Ca}^{2+}$ external saline and the nonspecific $\mathrm{Ca}^{2+}$ channel blocker $\mathrm{Cd}^{2+}$ abolished this $\mathrm{Ca}^{2+}$ increase. In agreement with our findings, a nitric oxide donor has been shown to elevate astrocytic $\mathrm{Ca}^{2+}$ (Bal-Price et al., 2002), and nitric oxide has been shown to trigger a $\mathrm{Ca}^{2+}$ influx into Bergmann glial cells (Matyash et al., 2001). In our studies, 8-Br-cGMP, an analog of cGMP, did not induce a detectable change in internal $\mathrm{Ca}^{2+}$, suggesting that the nitric oxide-induced $\mathrm{Ca}^{2+}$ increase is mediated by a cGMPindependent pathway. Similarly, nitric oxide can induce a cGMPindependent $\mathrm{Ca}^{2+}$ influx in endothelial cells (Berkels et al., 2000). In contrast, another group has reported nitric oxideinduced $\mathrm{Ca}^{2+}$ mobilization that is mediated by cGMP kinasedependent activation of ryanodine receptors (Willmott et al., 2000). However, because they used mixed cultures of astrocytes and neurons, they were unable to confirm that the NO effect that they observed in astrocytes was attributable to NO stimulation of astrocytes or attributable to NO stimulation of adjacent neurons.

The nitric oxide-induced $\mathrm{Ca}^{2+}$ influx in astrocytes is blocked by $2-\mathrm{APB}$, an antagonist of the capacitative $\mathrm{Ca}^{2+}$ entry pathway, and by $\mathrm{Gd}^{3+}$ (Bal-Price et al., 2002), suggesting that this nitric oxide-induced $\mathrm{Ca}^{2+}$ influx is through store-operated $\mathrm{Ca}^{2+}$ channels. Because $S$-nitrosylation is emerging as an important specific post-translational modification of numerous proteins (Stamler et al., 2001), including store-operated $\mathrm{Ca}^{2+}$ channels (Favre et al., 1998; Ma et al., 1999; van Rossum et al., 2000), nitric oxide might directly modulate store-operated channels and thus induce an influx of $\mathrm{Ca}^{2+}$.

To further understand the consequences of nitric oxideinduced $\mathrm{Ca}^{2+}$ influx in astrocytes and to ask whether storeoperated $\mathrm{Ca}^{2+}$ channels might be a target, we determined whether nitric oxide could modulate the refilling of internal $\mathrm{Ca}^{2+}$ stores. We directly imaged changes in internal stores of $\mathrm{Ca}^{2+}$ and simultaneously monitored the changes in cytosolic $\mathrm{Ca}^{2+}$. Although membrane-permeant, chemically synthesized ion indicators are not specifically targeted to subcellular compartments, the loading of cells with low-affinity (mag-fluo-4) and high-affinity (X-rhod-1) indicators at high and low temperatures biased these two indicators to report $\mathrm{Ca}^{2+}$ levels of store and cytosolic locales, respectively. These two $\mathrm{Ca}^{2+}$ indicators reported the simultaneous depletion of internal store $\mathrm{Ca}^{2+}$ and the elevation of cytosolic $\mathrm{Ca}^{2+}$ in response to thapsigargin and to ATP, demonstrating that they effectively monitor the relative $\mathrm{Ca}^{2+}$ levels of these two compartments.

Several mechanisms have been proposed as mediators of the coupling between the depletion of internal $\mathrm{Ca}^{2+}$ stores and the stimulation of the $\mathrm{Ca}^{2+}$ influx pathway. These include the following: (1) conformational coupling in which the $\mathrm{IP}_{3}$ receptor is physically coupled to plasma membrane $\mathrm{Ca}^{2+}$ influx channels; (2) release of a diffusible $\mathrm{Ca}^{2+}$ influx factor from the ER; (3) negative regulation of $\mathrm{Ca}^{2+}$ influx channels by cytosolic $\mathrm{Ca}^{2+}$; 
and (4) an exocytic mechanism in which depletion of stores leads to the insertion into the plasma membrane of vesicles containing $\mathrm{Ca}^{2+}$ influx channels (Putney et al., 2001). By chelating nitric oxide through the addition of PTIO or by blocking nitric oxide synthesis with L-NMMA, we identified the presence of an additional pathway in which the elevation of cytosolic $\mathrm{Ca}^{2+}$, which results from store depletion, causes the $\mathrm{Ca}^{2+}$-dependent synthesis of a chemical factor, nitric oxide. This in turn induces the activation of $\mathrm{Ca}^{2+}$ influx pathway that contributes to the refilling of $\mathrm{Ca}^{2+}$ stores. Whether this $\mathrm{Ca}^{2+}$ influx pathway is mediated by transient receptor potential channels or $I_{\text {CRAC }}$ awaits further investigation. It is important to note that this pathway, which we will term the $\mathrm{Ca}^{2+}$-induced $\mathrm{Ca}^{2+}$ influx factor, operates in parallel with other mechanisms because the PTIO-sensitive component of $\mathrm{Ca}^{2+}$ store refilling represents only a portion of the storerefilling pathway.

\section{References}

Akaike T, Yoshida M, Miyamoto Y, Sato K, Kohno M, Sasamoto K, Miyazaki K, Ueda S, Maeda H (1993) Antagonistic action of imidazolineoxyl $\mathrm{N}$-oxides against endothelium-derived relaxing factor/NO through a radical reaction. Biochemistry 32:827-832.

Araque A, Parpura V, Sanzgiri RP, Haydon PG (1998a) Glutamatedependent astrocyte modulation of synaptic transmission between cultured hippocampal neurons. Eur J Neurosci 10:2129-2142.

Araque A, Sanzgiri RP, Parpura V, Haydon PG (1998b) Calcium elevation in astrocytes causes an NMDA receptor-dependent increase in the frequency of miniature synaptic currents in cultured hippocampal neurons. J Neurosci 18:6822-6829.

Araque A, Parpura V, Sanzgiri RP, Haydon PG (1999) Tripartite synapses: glia, the unacknowledged partner. Trends Neurosci 22:208-215.

Bal-Price A, Moneer Z, Brown GC (2002) Nitric oxide induces rapid, calcium-dependent release of vesicular glutamate and ATP from cultured rat astrocytes. Glia 40:312-323.

Berkels R, Suerhoff S, Roesen R, Klaus W (2000) Nitric oxide causes a cGMP-independent intracellular calcium rise in porcine endothelial cells-a paradox? Microvasc Res 59:38-44.

Bezzi P, Carmignoto G, Pasti L, Vesce S, Rossi D, Rizzini BL, Pozzan T, Volterra A (1998) Prostaglandins stimulate calcium-dependent glutamate release in astrocytes. Nature 391:281-285.

Birnbaumer L, Zhu X, Jiang M, Boulay G, Peyton M, Vannier B, Brown D, Platano D, Sadeghi H, Stefani E, Birnbaumer M (1996) On the molecular basis and regulation of cellular capacitative calcium entry: roles for Trp proteins. Proc Natl Acad Sci USA 93:15195-15202.

Bootman MD, Collins TJ, Mackenzie L, Roderick HL, Berridge MJ, Peppiatt CM (2002) 2-Aminoethoxydiphenyl borate (2-APB) is a reliable blocker of store-operated $\mathrm{Ca}^{2+}$ entry but an inconsistent inhibitor of InsP3induced $\mathrm{Ca}^{2+}$ release. FASEB J 16:1145-1150.

Brenman JE, Bredt DS (1997) Synaptic signaling by nitric oxide. Curr Opin Neurobiol 7:374-378.

Brenman JE, Chao DS, Gee SH, McGee AW, Craven SE, Santillano DR, Wu Z, Huang F, Xia H, Peters MF, Froehner SC, Bredt DS (1996) Interaction of nitric oxide synthase with the postsynaptic density protein PSD-95 and alpha1-syntrophin mediated by PDZ domains. Cell 84:757-767.

Broillet M, Randin O, Chatton J (2001) Photoactivation and calcium sensitivity of the fluorescent NO indicator 4, 5-diaminofluorescein (DAF-2): implications for cellular NO imaging. FEBS Lett 491:227-232.

Burette A, Zabel U, Weinberg RJ, Schmidt HH, Valtschanoff JG (2002) Synaptic localization of nitric oxide synthase and soluable guanylyl cyclase in the hippocampus. J Neurosci 22:8961-8970.

Charles AC (1994) Glia-neuron intercellular calcium signaling. Dev Neurosci 16:196-206.

Charles AC, Dirksen ER, Merrill JE, Sanderson MJ (1993) Mechanisms of intercellular calcium signaling in glial cells studied with dantrolene and thapsigargin. Glia 7:134-145.

Clapham DE (1995) Intracellular calcium. Replenishing the stores. Nature 375:634-635.

Clapham DE, Runnels LW, Strubing C (2001) The TRP ion channel family. Nat Rev Neurosci 2:387-396.

Cornell-Bell AH, Finkbeiner SM, Cooper MS, Smith SJ (1990) Glutamate induces calcium waves in cultured astrocytes: long-range glial signaling. Science 247:470-473.

Crepel F (1998) Nitric oxide and long-term depression in the cerebellum. Trends Neurosci 21:63-64.

Dani JW, Chernjavsky A, Smith SJ (1992) Neuronal activity triggers calcium waves in hippocampal astrocyte networks. Neuron 8:429-440.

Favre CJ, Ufret-Vincenty CA, Stone MR, Ma HT, Gill DL (1998) $\mathrm{Ca}^{2+}$ pool emptying stimulates $\mathrm{Ca}^{2+}$ entry activated by S-nitrosylation. J Biol Chem 273:30855-30858.

Furchgott RF, Zawadzki JV (1980) The obligatory role of endothelial cells in the relaxation of arterial smooth muscle by acetylcholine. Nature 288:373-376.

Golovina VA, Blaustein MP (2000) Unloading and refilling of two classes of spatially resolved endoplasmic reticulum $\mathrm{Ca}^{2+}$ stores in astrocytes. Glia 31:15-28.

Griffith OW, Stuehr DJ (1995) Nitric oxide synthases: properties and catalytic mechanism. Annu Rev Physiol 57:707-736.

Gross SS, Wolin MS (1995) Nitric oxide: pathophysiological mechanisms. Annu Rev Physiol 57:737-769.

Guihard G, Combettes L, Capiod T (1996) 3':5'-cyclic guanosine monophosphate (cGMP) potentiates the inositol 1, 4, 5-trisphosphate-evoked $\mathrm{Ca}^{2+}$ release in guinea-pig hepatocytes. Biochem J 318:849-855.

Guthrie PB, Knappenberger J, Segal M, Bennett MV, Charles AC, Kater SB (1999) ATP released from astrocytes mediates glial calcium waves. J Neurosci 19:520-528.

Hassinger TD, Atkinson PB, Strecker GJ, Whalen LR, Dudek FE, Kossel AH, Kater SB (1995) Evidence for glutamate-mediated activation of hippocampal neurons by glial calcium waves. J Neurobiol 28:159-170.

Hawkins RD, Son H, Arancio O (1998) Nitric oxide as a retrograde messenger during long-term potentiation in hippocampus. Prog Brain Res 118:155-172.

Holscher C (1997) Nitric oxide, the enigmatic neuronal messenger: its role in synaptic plasticity. Trends Neurosci 20:298-303.

Hoth M, Penner R (1993) Calcium release-activated calcium current in rat mast cells. J Physiol (Lond) 465:359-386.

Ignarro LJ, Buga GM, Wood KS, Byrns RE, Chaudhuri G (1987) Endothelium-derived relaxing factor produced and released from artery and vein is nitric oxide. Proc Natl Acad Sci USA 84:9265-9269.

Innocenti B, Parpura V, Haydon PG (2000) Imaging extracellular waves of glutamate during calcium signaling in cultured astrocytes. J Neurosci 20:1800-1808.

Jaffrey SR, Snyder SH (1995) Nitric oxide: a neural messenger. Annu Rev Cell Dev Biol 11:417-440.

Kang J, Jiang L, Goldman SA, Nedergaard M (1998) Astrocyte-mediated potentiation of inhibitory synaptic transmission. Nat Neurosci 1:683-692.

Kojima H, Urano Y, Kikuchi K, Higuchi T, Hirata Y, Nagano T (1999) Fluorescent indicators for imaging nitric oxide production. Angew Chem Int Ed Engl 38:3209-3212.

Lee HC (1997) Mechanisms of calcium signaling by cyclic ADP-ribose and NAADP. Physiol Rev 77:1133-1164.

Lewis RS, Cahalan MD (1989) Mitogen-induced oscillations of cytosolic $\mathrm{Ca}^{2+}$ and transmembrane $\mathrm{Ca}^{2+}$ current in human leukemic T cells. Cell Regul 1:99-112.

Lipton SA, Singel DJ, Stamler JS (1994) Nitric oxide in the central nervous system. Prog Brain Res 103:359-364.

Loitto VM, Nilsson H, Sundqvist T, Magnusson KE (2000) Nitric oxide induces dose-dependent $\mathrm{Ca}^{2+}$ transients and causes temporal morphological hyperpolarization in human neutrophils. J Cell Physiol 182:402-413.

Looms DK, Tritsaris K, Nauntofte B, Dissing S (2001) Nitric oxide and cGMP activate $\mathrm{Ca}^{2+}$-release processes in rat parotid acinar cells. Biochem J 355:87-95.

Ma HT, Favre CJ, Patterson RL, Stone MR, Gill DL (1999) $\mathrm{Ca}^{2+}$ entry activated by S-nitrosylation. Relationship to store-operated $\mathrm{Ca}^{2+}$ entry. J Biol Chem 274:35318-35324.

Matyash V, Filippov V, Mohrhagen K, Kettenmann H (2001) Nitric oxide signals parallel fiber activity to Bergmann glial cells in the mouse cerebellar slice. Mol Cell Neurosci 18:664-670.

Murphy S (2000) Production of nitric oxide by glial cells: regulation and potential roles in the CNS. Glia 29:1-13. 
Nedergaard M (1994) Direct signaling from astrocytes to neurons in cultures of mammalian brain cells. Science 263:1768-1771.

Newman EA, Zahs KR (1998) Modulation of neuronal activity by glial cells in the retina. J Neurosci 18:4022-4028.

Palmer RM, Ferrige AG, Moncada S (1987) Nitric oxide release accounts for the biological activity of endothelium-derived relaxing factor. Nature 327:524-526.

Parekh AB, Penner R (1997) Store depletion and calcium influx. Physiol Rev 77:901-930.

Parpura V, Haydon PG (2000) Physiological astrocytic calcium levels stimulate glutamate release to modulate adjacent neurons. Proc Natl Acad Sci USA 97:8629-8634.

Parpura V, Basarsky TA, Liu F, Jeftinija K, Jeftinija S, Haydon PG (1994) Glutamate-mediated astrocyte-neuron signalling. Nature 369:744-747.

Parpura V, Yu F, Basarsky T, Jahn R, Haydon PG (1995) Expression of synaptobrevin II, cellubrevin and syntaxin but not SNAP-25 in cultured astrocytes. FEBS Letters 377:489-492.

Pasti L, Volterra A, Pozzan T, Carmignoto G (1997) Intracellular calcium oscillations in astrocytes: a highly plastic, bidirectional form of communication between neurons and astrocytes in situ. J Neurosci 17:7817-7830.

Porter JT, McCarthy KD (1996) Hippocampal astrocytes in situ respond to glutamate released from synaptic terminals. J Neurosci 16:5073-5081.

Putney Jr JW (1977) Muscarinic, alpha-adrenergic and peptide receptors regulate the same calcium influx sites in the parotid gland. J Physiol (Lond) 268:139-149.

Putney Jr JW, McKay RR (1999) Capacitative calcium entry channels. BioEssays 21:38-46.

Putney Jr JW, Broad LM, Braun FJ, Lievremont JP, Bird GS (2001) Mechanisms of capacitative calcium entry. J Cell Sci 114:2223-2229.

Rooney TA, Joseph SK, Queen C, Thomas AP (1996) Cyclic GMP induces oscillatory calcium signals in rat hepatocytes. J Biol Chem 271:19817-19825.

Salter MW, Hicks JL (1995) ATP causes release of intracellular $\mathrm{Ca}^{2+}$ via the phospholipase C beta/IP3 pathway in astrocytes from the dorsal spinal cord. J Neurosci 15:2961-2971.

Schuman EM, Madison DV (1994) Nitric oxide and synaptic function. Annu Rev Neurosci 17:153-183.

Shmigol AV, Eisner DA, Wray S (2001) Simultaneous measurements of changes in sarcoplasmic reticulum and cytosolic. J Physiol (Lond) 531:707-713.

Stamler JS, Lamas S, Fang FC (2001) Nitrosylation. the prototypic redoxbased signaling mechanism. Cell 106:675-683.

van Rossum DB, Patterson RL, Ma HT, Gill DL (2000) $\mathrm{Ca}^{2+}$ entry mediated by store depletion, S-nitrosylation, and TRP3 channels. Comparison of coupling and function. J Biol Chem 275:28562-28568.

Venance L, Stella N, Glowinski J, Giaume C (1997) Mechanism involved in initiation and propagation of receptor-induced intercellular calcium signaling in cultured rat astrocytes. J Neurosci 17:1981-1992.

Volk T, Mading K, Hensel M, Kox WJ (1997) Nitric oxide induces transient $\mathrm{Ca}^{2+}$ changes in endothelial cells independent of cGMP. J Cell Physiol 172:296-305.

Volterra A, Magistretti PJ, Haydon PG, eds (2002) The tripartite synapse: glia in synaptic transmission. Oxford: Oxford UP.

Willmott N, Sethi JK, Walseth TF, Lee HC, White AM, Galione A (1996) Nitric oxide-induced mobilization of intracellular calcium via the cyclic ADP-ribose signaling pathway. J Biol Chem 271:3699-3705.

Willmott NJ, Galione A, Smith PA (1995) Nitric oxide induces intracellular $\mathrm{Ca}^{2+}$ mobilization and increases secretion of incorporated 5-hydroxytryptamine in rat pancreatic beta-cells. FEBS Lett 371:99-104.

Willmott NJ, Wong K, Strong AJ (2000) A fundamental role for the nitric oxide-G-kinase signaling pathway in mediating intercellular $\mathrm{Ca}^{2+}$ waves in glia. J Neurosci 20:1767-1779.

Zhang L, McCloskey MA (1995) Immunoglobulin E receptor-activated calcium conductance in rat mast cells. J Physiol (Lond) 483:59-66. 